\title{
THE MICROANALYSIS OF POLITICAL DISCOURSE
}

\author{
Peter Bull \\ Department of Psychology, University of York, UK
}

\begin{abstract}
Resumen: El microanálisis representa tanto una metodología como una manera distintiva de interpretar la comunicación. En este artículo se estudia su aplicación al análisis del discurso político en relación a tres conceptos claves: el modelo de destrezas sociales de la interacción social, la imagen y la labor de la imagen, y el papel del contexto social (especialmente géneros de comunicación). A través de las técnicas del microanálisis se pueden analizar las destrezas comunicativas de los políticos, en concreto sus capacidades para llevar a cabo una labor de la imagen efectiva en diferentes contextos sociales.
\end{abstract}

Palabras clave: microanálisis, imagen, labor de la imagen, modelo de destrezas sociales, géneros de la comunicación.

Abstract: Microanalysis represents both a distinctive methodology and a distinctive way of thinking about communication. Its application to the analysis of political discourse is discussed in relation to three key concepts: the social skills model of social interaction; face and facework; the role of social context (especially genres of communication). Through microanalytic techniques the communicative skills of politicians can be analysed, in particular their ability to perform effective facework in different social contexts.

Keywords: microanalysis; face; facework; social skills model; genres of communication.

\section{INTRODUCTION}

Microanalysis represents not only a distinctive methodology but also a distinctive way of thinking about communication (Bull, 2002, 2008). It is characterized by a belief in the value of studying the fine details of social interaction through the analysis of film, audiotape and videotape recordings. Microanalytic research on political discourse has been conducted in particular on broadcast interviews and speeches: for example, on how politicians interviews cope with interruptions, on how and why they equivocate in response to awkward questions, and on how rhetorical devices and nonverbal delivery are used to invite audience applause (e.g., Bull, 2003). 
In contemporary politics, the mass media are of central importance, as is the ability of politicians to communicate through the mass media. Contemporary politics is mediated politics, politicians communicate both with each other and with the electorate especially through television. Politicians are not only seen and heard, they are seen and heard in close-up; their appearance, indeed their every action are open to close scrutiny. Thus, what matters is not just what is said but how it is said: demeanour, tone of voice, facial expression and body movement may all affect voters' perceptions of their political representatives. For a politician to be good on television is a major political asset, given that television has now become such a significant part of the contemporary political process.

But in the context of political discourse, it will be argued in this article that microanalysis needs to be considered in relation to a number of other key concepts. Specifically, these are the proposal that communication can be regarded as a skill, that the performance of appropriate facework is a key political skill, and that communication needs to be understood in social context, with particular regard to different genres of communication. Each of these concepts will be discussed in turn.

\section{COMMUNICATION AS SKILL}

In "The experimental analysis of social performance", Argyle and Kendon (1967) proposed that social behaviour can be understood as a form of skill. Social behaviour, they argued, involves processes comparable to those involved in motor skills, such as driving a car or playing a game of tennis. Given that we already know a great deal about motor skill processes, they argued that this knowledge could be used to advance our understanding of social interaction. They identified six processes as common to motor skills and social performance: distinctive goals, selective perception of cues, central translation processes, motor responses, feedback and corrective action, and the timing of responses.

In recent years, Argyle and Kendon's model has been significantly revised and updated by Hargie (e.g., Hargie \& Marshall 1986; Hargie 1997; Hargie 2006a, 2006b). Although Hargie fully acknowledged the value and significance of the analogy between social and motor skills, he proposed four important differences:

1. Since social interaction by definition involves other people, it is necessary to consider the goals not only of one individual but of all those involved, as well as their actions and reactions towards one another.

2. The perception of persons differs in a number of ways from the perception of objects. We perceive the responses of the other person with whom we communicate. We may also perceive our own responses, in that we hear what we say, and can be aware of our own nonverbal behaviour. We make judgments about how other people perceive us, and we may also attempt to ascertain how they 
think we perceive them. Such judgments may influence our own behaviour during social interaction.

3. The role of feelings and emotions is neglected by the original social skills model. Mood and emotional state can have an important bearing on responses, goals and perceptions in social interaction. Furthermore, whereas we often take into account the feelings of other people with whom we interact, this is clearly not the case in learning to perform a motor skill.

4. The social situation in which interaction occurs is important, for example, the roles which people play, the rules governing the situation, the nature of the task, and the physical environment. In addition, personal factors, such as age, gender and physical appearance, will be important in the way in which people behave towards one another.

Although neither versions of the social skills model were intended to encompass political behaviour, Bull (forthcoming) has argued that the model has significant implications for our understanding of what makes a successful politician. These are detailed below.

1. The proposal that social behaviour is goal-directed is particularly relevant to politics. For example, in a general election campaign, a political party needs a coherent set of policies to bring to the electorate. Indeed, politicians may be criticized for lacking clear vision or purpose. Furthermore, politicians must consider not only their own goals, but the goals of others which may conflict with their own aspirations, most notably in the case of opposing politicians.

2. Perceptual skills play a significant role. Undoubtedly, it is important for politicians to read people and situations well, since this will affect how they behave towards others. But not only do politicians need to be good at perceiving others, as public figures they need to be aware of how others perceive them. Thus, in a study based on the 2001 British general election, ratings of political leaders were shown to be one of the two best predictors of how people voted (Clarke, Sanders, Stewart \& Whiteley 2004). Factor analysis of these ratings showed two distinct but interrelated dimensions, labelled competence and responsiveness. Ratings of "keeps promises," "decisive" and "principled" loaded on competence; ratings of "caring," "listens to reason" and "not arrogant" loaded on responsiveness (Clarke et al. 2004). In a previous analysis of leader ratings based on the 1987 British general election, Stewart and Clarke (1992) identified the same two factors. Accordingly, Clarke et al. (2004) proposed that competence and responsiveness may be regarded as two enduring dimensions of how British political leaders are perceived. From this perspective, politicians must endeavour to be seen as both competent and responsive, since failing on either dimension may lose them electoral support. 
3. The term "central translation processes" in the original social skills model (Argyle \& Kendon 1967) referred to the planning aspect of behaviour, the rules by which a particular signal is interpreted as regarding a particular action. However, this term was widely regarded as too restrictive, and replaced with the broader term "mediating factors" (Hargie, e.g., 2006a). A good example of mediating factors are the concepts of face and facework. Face is defined by Goffman as "the positive social value a person effectively claims for himself by the line others assume he has taken during a particular contact" (Goffman 1967:5), facework the actions people take to protect threats to the face of both themselves and others. There is now an extensive research literature attesting to the importance of face and facework in political discourse (e.g., Bull, 2008; Bull \& Fetzer, in press), which is discussed more fully in Section 2 below.

4. Motor responses refer to the performance of actual behaviour. It is not enough for a politician to be a skilled perceiver, or to be able to translate perceptions into appropriate behavioural strategies; the behaviour itself has to be performed in a convincing and effective manner. Motor responses can refer to both speech and nonverbal behaviour, and their respective integration and synchronization. These are discussed further below in sections 2 and 3, with respect both to facework and genres of communication.

5. Feedback and corrective action refer to the ways in which an individual may modify his behaviour in the light of feedback from others. There are many different forms of feedback available to politicians. Political activity receives intense coverage through television, the internet and through newspapers. Politicians themselves continuously monitor each other's activities, evaluating and criticising each other's performance. The electorate can also give feedback through opinion polls, focus groups, writing to their Member of Parliament (MP), and of course through elections themselves. In fact, so much feedback is available to politicians that their real skill may lie in knowing how to respond appropriately, in avoiding the twin dangers of over-reaction and under-reaction.

6. Good timing and rhythm are important features of social skills. Synchronization of behaviour is an important aspect of timing. This may involve both synchronizing one's own behaviour, and co-ordinating the behaviour of others. For example, making effective points in a political debate may require skilled timing, such that a point is made neither too early nor too late. Jumping in too soon to interrupt an opponent before s/he has finished a point may be perceived as rude and aggressive, but attempting to make a counterargument to a previous point once the discussion has moved on to a different topic may seem pedestrian and inappropriate.

7. Social skills need to be understood in terms of what Hargie (e.g., 1997) terms the person-situation context. With regard to political behaviour, contextual 
factors may be considered from a whole variety of perspectives. Notoriously, the discourse politicians employ during an election campaign may differ substantively from that after they win office. A speech made by a politician after an election victory will differ substantively from one made in the context of a political scandal. Furthermore, the communication skills required for a politician to perform well in one context may differ from those required in another. In Section 3 of this article, contextual factors are discussed with particular respect to different modalities of communication.

Not only has the social skills model contributed to our understanding of social interaction and interpersonal communication (Bull 2002), it also has significant practical applications. If social interaction is a skill, then it should be possible for people to learn to interact more effectively, just as it is possible to improve performance on any other skill (Argyle and Kendon 1967). This proposal was formalised in what was termed social skills training. Currently, it is better known as communication skills training (CST), and has been used extensively in a wide variety of social contexts (e.g., Hargie 2006c). There is now an substantive research literature on CST (e.g., Hargie 2006c), although there are no published studies of formal CST with politicians; nevertheless, there are plenty of anecdotal examples. For example, the recent British general election of 2010 saw the introduction for the first time of televised Prime Ministerial debates between the leaders of the three main political parties (Labour, Conservative and Liberal Democrat). Each party conducted its own rehearsals for the debates, with other well-known political figures playing the role of each of the party leader's opponents. Such rehearsals can readily be understood as a form of CST for what was a novel genre of political communication in the United Kingdom.

\section{FACE AND FACEWORK}

In the sphere of politics, an important mediating factor is what Johansson (2008) has referred to as "the presentation of the political self", based on Goffman's (1959/1990) seminal book "The Presentation of Self in Everyday Life"s. Goffman analyzed social interaction as if it were part of a theatrical performance, arguing that people in everyday life are like actors on a stage, managing settings, clothing, words, and nonverbal behaviour to give a particular impression. As discussed above, voter perceptions are extremely important, consequently politicians must strive to create a favourable impression on the electorate, through controlling or managing the impressions or perceptions formed by others. This process can be usefully analysed through the related concepts of face and facework (Goffman, 1955/1967).

Face is important in all cultures; it can be lost, maintained or enhanced, according to Brown and Levinson's $(1978,1987)$ highly influential theory of politeness. Thus, face preservation is a primary constraint on the achievement of 
goals in social interaction. "Some acts are intrinsically threatening to face and thus require 'softening"' (Brown \& Levinson 1978: 24). Communicative actions such as commands or complaints may be performed in such a way as to minimise the threat to positive and negative face, where positive face is defined as "the want of every member that his wants be desirable to at least some others", negative face as "the want of every 'competent adult member' that his actions be unimpeded by others" (Brown \& Levinson 1987: 62). So, for example, a request to do something may threaten someone's negative face (by restricting their freedom of action), whereas disagreements may threaten positive face (by showing a lack of approval).

Although Brown and Levinson's $(1978,1987)$ conceptualisation of face is known as politeness theory, the terms face and politeness are not synonymous. Politeness is a form of facework, but not the only one. Indeed, Goffman (1955/1967) specified three kinds of facework: an avoidance process (avoiding potentially face-threatening acts), a corrective process (performing a variety of redressive acts), and also what he called making points (the aggressive use of facework). The latter was elaborated in Goffman's (1967) extended essay "Where the Action Is", where he discussed incidents in which adversaries deliberately antagonize one another; the focus is on who will back down in such situations, and on what counts as backing down. Interestingly, although Brown and Levinson $(1978,1987)$ were indebted to Goffman's $(1955 / 1967)$ analysis of facework, they overlooked such instances of deliberate face aggravation. Within the framework of politeness theory, rudeness is envisaged simply as a deviation from or violation of rules of cooperative/polite communication. In fact, rudeness can be deliberate and motivated, if not calculated and strategic (Kienpointer, 1997). Culpeper (1996) has argued that in some contexts (e.g., army training and literary drama) impoliteness is not a marginal activity, but central to the interaction that takes place.

Arguably, another such context is that of adversarial political discourse (Bull $\&$ Fetzer, in press). Insults are one very characteristic form of face aggravation, and were analyzed by Ilie $(2001,2004)$ in the context of parliamentary debates in the United Kingdom and Sweden. Other forms of face aggravation were analysed by Harris (2001) in the context of Prime Minister's Questions (PMQ), the weekly sessions in the British House of Commons in which the Prime Minister is open to questions from any MP. Harris argued that much of the discourse of PMQ is composed of intentional and explicitly face-threatening acts, and gives a number of illustrative examples. Hence, PMQ can be seen as another setting in which impoliteness is central to the interaction that takes place. Harris' research is discussed further in Section 3 on social context.

The concepts of positive and negative face (Brown \& Levinson, 1978/1987) are also highly relevant to the analysis of political discourse (Bull \& Fetzer, in press). Thus, according to Jucker, "It is clear that what is primarily at issue in news 
interviews is the interviewee's positive face" (Jucker 1986: 71). Upholding positive face, Jucker proposed, is of particular importance for democratically-elected politicians in the context of political interviews. This is because their political survival ultimately depends on the approval of a majority of people in their own constituency. Conversely, Jucker argued that negative face is of little importance in news interviews, because the politician by consenting to be interviewed has already consented to his/her freedom of action being limited in this way.

In fact, if positive face is essentially the need to be well regarded by others, it is of fundamental importance for politicians not only in interviews, but also in other situations, for example when making a speech, debating with another politician, or responding to a question from a member of the public. A politician who suffers serious loss of positive face may come to be regarded as a liability by his or her political party. A government minister or an opposition front bench spokesperson may come under pressure to resign; an MP may be defeated at the next general election, or if deselected, may not even be allowed to stand for election as the party's parliamentary candidate.

But negative face is also important. Even in news interviews, where Jucker (1986) downplayed its significance, politicians may suffer serious potential face damage through responses to questions which circumscribe future freedom of action. If, for example, the leader of the British Conservative Party categorically asserted that the party would never to go into coalition with the Liberal Democrats, $\mathrm{s} /$ he would suffer serious face loss if in the event of a hung Parliament, $\mathrm{s} /$ he formed such a coalition because it was the only way of securing a parliamentary majority. As Goffman (1955/1967) pointed out, people need to protect their face against even the possibility of threat: they avoid performing actions which although acceptable in the present may reflect badly upon them in the future. Hence, a politician will be careful to avoid making statements which may hamper or constrain his/her future freedom of action. This point is effectively summed up in the old political saw: "Never say never". Thus, issues of positive and negative face may both be addressed in political discourse; they should not be seen as alternatives, rather their relative importance may vary according to situational context, as may the role of face aggravation.

The term "facework" was introduced by Goffman (1955/1967) to refer to actions taken to counteract the threats to face by avoidance or corrective processes; facework may also be performed in the form of face aggravation, as described above. Notably, facework can be seen as a form of communicative skill, and a highly important one for democratically-elected politicians. A study of facework in political interviews broadcast during the 1992 British general election was conducted by the author and his colleagues (Bull, Elliott, Palmer \& Walker 1992). They developed a typology of how questions pose threats to face, identifying 19 different types of face-threat. These were grouped into three superordinate categories (threats to the political party the politician represents, threats 
to self and threats to significant others). For example, the question "Why do you think your party is doing so badly in the opinion polls" would threaten the face of the party the politician represents. In contrast, the question "Do you not think the public is entitled to regard your own expenses' claims as unreasonable?" would threaten the face of the individual politician. On the basis of equivocation theory (Bavelas, Black, Chovil, \& Mullett 1990), Bull et al. proposed and confirmed the hypothesis that politicians would typically equivocate more to those questions where all the principal forms of response posed a threat to face.

Elsewhere, the author has developed an equivocation typology (Bull \& Mayer 1993; Bull 2003). This typology is divided into superordinate and subordinate categories. For example, one superordinate category is attacks the question. This can be further subdivided into eight subordinate categories, for example, the question is hypothetical or speculative, the question is based on a false premise, the question includes a misquotation. In total, there are 12 superordinate categories. When these categories are further subdivided into subordinate categories, 35 ways of not answering a question can be distinguished. Some of these may be seen as highly skilled, some less so, others as transparently evasive or even downright inept.

For example, Tony Blair made skilful use of the term "modernisation" in the general election campaign of 1997 to equivocate and present the best possible face in response to awkward questions regarding the dramatic policy changes in the Labour Party which had taken place in the preceding 15 years (Bull, 2000). In contrast, Neil Kinnock (Labour Party leader, 1983-1992) made use of what were termed negative answers, where he stated what would not happen rather than what would happen. This was deemed an ineffectual, face-damaging form of equivocation, since interviewers would simply reiterate the question ("That is why I am asking you what you would do"), thereby drawing attention to the preceding equivocation and making Kinnock look evasive. Thus, different forms of equivocation may be seen as reflecting different levels of communicative skill, which may be understood in terms of face and face management. Politicians are frequently castigated for not replying to questions, but they are often placed in conflictual situations where it is not possible to answer a question directly; from this perspective, equivocation itself can be considered as form of communicative skill in its own right (Bull, 2010).

In summary, it is proposed that positive face, negative face and face aggravation are all important aspects of political facework. That is to say, politicians will seek to present themselves in a favourable light, to defend their freedom of action, and in an adversarial political system, to attack the face of their political opponents while defending their own. Through skilled facework, politicians may seek both to defend their own face and to undermine the face of their political opponents. But the significance of these different forms of facework cannot be considered just in the abstract. As Arundale (2006) points out, face is a 
relational and interactional rather than an individual phenomenon, in that the social self is interactionally achieved in relationship with others. From this perspective, the role of face and facework needs to be considered in situated context, which is discussed below.

\section{SOCLAL CONTEXT}

Social context can be analysed in a whole variety of ways. For example, whereas a politician in government may focus on defending, justifying or extolling the government's achievements, a politician in opposition may be more inclined to face aggravation to undermine that record. Again, political discourse will may vary according to the political audience. A speaker to the party faithful at an annual conference may seek to enthuse the audience through ingroup praise and/or outgroup derogation, whereas a speaker at a public meeting in a general election may be more concerned to woo undecided voters through policy commitments which address their particular concerns, and which flatter their positive face.

In seeking to understand the role of social context, a key concept is that of communication genre. In this section, four distinct genres of political communication will be discussed: broadcast interviews, parliamentary question time, political speeches and televised debates. Each genre can be seen as representing a different form of political discourse: specifically, politicians addressing an audience (monologue), politicians questioned by professional interviewers, politicians questioned by other politicians, and politicians in debate with one another. According to Thibault (2003, p.44), "Genres are types. But they are types in a rather peculiar way. Genres do not specify the lexicogrammatical resources of word, phrase, clause, and so on. Instead, they specify the typical ways in which these are combined and deployed so as to enact the typical semiotic action formations of a given community".

Broadcast interviews characteristically take the form of question-response sequences; the interviewer is expected to ask questions, to which the politician is expected to reply (e.g., Greatbatch, 1988; Clayman, 1989; Heritage, Clayman \& Zimmerman, 1988). This is the principal means used by interviewers for creating and sustaining talk (Schegloff, 1989), although they may also engage in non-questioning actions to open and close the interview (Heritage \& Greatbatch, 1991).

The adversarial nature of broadcast interviews has been analysed in some detail by Clayman and Heritage (2002). They identified a number of techniques for adversarial questioning, such as accusatory questions, and what they call splits, forks and contrasts, whereby the questioner highlights inconsistencies in the politician's own position, or disagreements with political allies. They also argued that adversarial questioning creates pressures on politicians towards evasiveness, and identified a number of techniques for evasion, both overt and 
covert. Overt techniques may involve requesting the interviewer's permission to shift the agenda, justifying an agenda shift, or even an outright refusal to answer. Covert techniques may include repeating the words of the question (without answering it), or modifying the question in such a way as to facilitate and conceal a shift in the agenda.

If broadcast interviews are adversarial, there is also a constraint on interviewers as journalists to be impartial. For example, according to the editorial guidelines of the BBC (British Broadcasting Corporation), "impartiality lies at the heart of the BBC's commitment to its audiences". Techniques for appearing impartial while conducting adversarial interviews have been identified by Clayman and Heritage (2002). Notably, the question-response format itself allows interviewers to defend their neutrality, on the grounds that "they are only asking questions". But within questions, interviewers may utilise embedded statements to disagree with, criticize or in some other way challenge the politician. Another device is the attribution of statements to third parties. This ensures that the interviewer's personal position is not on record, and neither the interviewer nor the news organization can be held responsible for statements which may be critical or even hostile to the politician. Through techniques such as embedded statements and third party attributions, interviewers may "... fulfil the complex journalistic requirement ... of being interactionally 'adversarial' while remaining officially 'neutral”' (Clayman 1992: 196).

Like a broadcast political interview, PMQ in the British House of Commons takes the form of question-response sequences. The principal difference is that the questions in PMQ are posed by opposing politicians, not by a professional political interviewer. Furthermore, whereas interviewers in broadcast interviews are expected to be impartial, there is no such requirement in PMQ: MPs can be as partial and as unashamedly partisan as they choose. Criticisms and accusations are permitted in the House. Furthermore, MPs are protected by parliamentary privilege, which allows them to speak freely in the House of Commons without fear of legal action on grounds of slander. However, they are expected to observe certain traditions and conventions with regard to what is termed "unparliamentary language" (for example, they should not be abusive or insulting).

Thus, in PMQ, MPs must orient both to the expectation that the dialogue should follow a question-answer pattern, and refrain from unacceptable unparliamentary language. Harris' (2001) study of PMQ discourse was based on 12 sessions recorded between March and November 2000. She gave a number of illustrative examples of the ways in which MPs perform intentionally facethreatening acts. Thus, one strategy is to ask a question which contains a request for highly specific information, which the Prime Minister may not have to hand, or may not wish to publicize. If the Prime Minister declines or fails to answer the question, the Leader of the Opposition may then subsequently provide the information in order to embarrass or attack the Prime Minister. Also 
common are questions based on face-threatening presuppositions. For example, David Cameron (Leader of the Conservative Opposition 2005-2010) asked Gordon Brown (Labour Prime Minister 2007-2010)"When is he going to give up his mania for state control and start trusting head teachers?" 24 October, 2007), thereby presupposing Gordon Brown had a "mania" for state control. Of course, the Prime Minister cannot answer such questions, without seemingly accepting such contentious presuppositions. Hence, the asking of unanswerable questions can be used as an additional source of face-threat, allowing Opposition MPs to criticize the Prime Minister for evasiveness. In addition, accusations and criticisms of the Prime Minister may be further intensified by the use of deliberately insulting lexical choices, such as "dodging questions", "pathetic", or "absolutely worthless" (Harris, 2001). A typology of FTAs has been developed by Bull and Law (2009), which distinguishes between 13 different techniques for performing face aggravation in PMQ.

Monologue was the focus of a series of ground-breaking studies by Atkinson (e.g., 1983, 1984a, 1984b). Notably, he showed how monologue can also be understood as an interactive event. He compared speaker-audience interaction to the way in which people take turns in conversation, although in the context of a political meeting, audience "turns" are essentially limited to gross displays of approval or disapproval (such as cheering or heckling). Atkinson further pointed out that audience responses are not random, indeed, they are highly synchronized with speech: typically applause occurs either just before or immediately after a possible completion point by the speaker. This close synchronization suggests that audience members must in some way be able to project possible completion points in advance of their occurrence. According to Atkinson, it is features in the construction of talk itself that indicate to the audience when to applaud.

In particular, he identified two distinctive formulaic rhetorical devices: threepart lists and contrasts. In a three-part list, once the listener recognizes that a list is under way, it is possible to anticipate the completion point (the end of the speaker's utterance), thereby signalling an appropriate place to applaud. The contrast (or antithesis) involves the sequential juxtaposition of an item with its opposite. To be effective, the second part of the contrast should closely resemble the first in the details of its construction and duration, so that the audience can more easily anticipate the point of completion. According to Atkinson, contrasts and three-part lists are by far the most frequently used devices for obtaining applause.

Atkinson's (e.g., 1983, 1984a 1984b) research was substantiated in a subsequent comprehensive study by Heritage and Greatbatch (1986) of all the 476 speeches broadcast from the British Conservative, Labour and Liberal Party conferences in 1981. In addition to three-part lists and contrasts, Heritage and Greatbatch identified a further five rhetorical devices used to invite applause. Overall, they found that $68 \%$ of the collective applause was associated with 
these seven rhetorical devices. Most effective were contrasts $(33.2 \%$ of collective applause incidences) and lists (12.6\%), the two rhetorical devices originally identified by Atkinson.

It should be noted that neither Atkinson (e.g., 1983, 1984a, 1984b) nor Heritage and Greatbatch (1986) focussed exclusively on the role of rhetorical devices in inviting applause, they also analysed at length the role of both delivery and speech content. Delivery refers to both the associated nonverbal and vocal behaviour. Whereas Atkinson argued that delivery simply increases the chance of a rhetorical device receiving applause, Bull and Wells (2002) proposed that delivery indicates whether or not the rhetorical device is to be taken as an applause invitation. They found that close synchronization between speech and applause only occurred when the delivery was congruent with an applause invitation. From this perspective, the skilled use of both appropriate delivery and rhetorical devices play important roles in synchronizing speaker-audience behaviour at political rallies.

A highly significant recent development in political communication in the United Kingdom has been the introduction of televised Prime Ministerial debates in the 2010 general election. These differed radically from the traditional broadcast interview in two particular respects. Although each debate was chaired by a professional broadcaster who selected which politician was to speak and also sought to control the length of their responses, it was notable that the politicians were able to address both one another as well as the audience. That is to say, the politicians' responses were not filtered through a professional broadcaster, and furthermore, all of the questions were posed not by interviewers but by members of the general public. Accordingly, this procedure enabled voters to make direct comparisons between the three party leaders and arguably highlighted both similarities and differences in policy.

These Prime Ministerial debates attracted huge audiences. The first, broadcast on independent television (ITV), was the most watched programme of the day, with average viewing figures of 9.4 million (37\% audience share). The second, broadcast on Sky News, Sky 3 and the BBC News Channel, was watched by 4.1 million, one of the largest audiences yet for a digital broadcast. The final debate, broadcast on the BBC and Sky News, was watched by 8.4 million (32.4\% audience share) (all viewing figures from The Guardian, Saturday 1 May 2010, p. 13). Although there is a well-established tradition in the USA of presidential debates, such encounters had never taken place in the United Kingdom before 2010. As such, they represent a new and distinctive genre of political communication in the United Kingdom.

\section{CONCLUSIONS}

In this paper, it has been argued that the microanalysis of political discourse needs to be considered in relation to a number of other key concepts: specifically, 
communication skill, face and facework, and social context. Arguably, the social skills model provides a framework within which to analyse politicians' communication skills. Furthermore, it helps to specify what those skills are, for example, to be good at perceiving others, to be aware of how one is perceived by others, to be skilled in facework and impression management. But communication skills need to be considered in social context. A good public speaker may not necessarily be a good debater or a good interviewee, situations which may require greater verbal dexterity and an ability to think on one's feet, in contrast to monologue, which can be fully prepared in advance. Nor will the politician who is skilled in face enhancement necessarily be skilled in face aggravation, or in resisting or countering face aggravation. But a politician who has the versatility to master communication skills in different social settings will be at a distinct advantage.

In contemporary politics, a politician's communication skills are arguably of central importance, especially given the salient power and influence of the mass media. Contemporary politics is mediated politics, politicians communicate both with each other and with the electorate especially through television. Microanalysis provides a powerful set of tools for analysing politicians' communicative skills and their ability to perform effectively in different social contexts.

\section{REFERENCES}

Argyle, M., \& Kendon, A. (1967). "The experimental analysis of social performance". Advances in Experimental Social Psychology 3, 55-97.

Arundale, R.B. (2006). "Face as relational and interactional: a communication framework for research on face, facework, and politeness". Journal of Politeness Research 2, 193-216.

Atкinson, J.M. (1983). "Two devices for generating audience approval: a comparative study of public discourse and text". Connectedness in Sentence, Text and Discourse, K.Ehlich \& H.van Riemsdijk (eds.), Tilburg, Netherlands: Tilburg papers in Linguistics, 199-236.

—, (1984a). Our Masters' Voices, London \& New York: Methuen.

—, (1984b). "Public speaking and audience responses: some techniques for inviting applause". Structures of Social Action: Studies in Conversation Analysis, J.M. Atkinson \& J.C. Heritage (eds.), Cambridge \& New York: Cambridge University Press, 370-409.

Bavelas, J.B., Black, A., Chovil, N., \& Mullett, J. (1990). Equivocal Communication, Newbury Park: Sage.

Brown, P., \& Levinson, S.C. (1978). "Universals in language usage: politeness phenomena", Questions and Politeness, E. Goody (ed.),Cambridge: Cambridge University Press, 56-310.

—, (1987). Politeness: Some Universals in Language Use, Cambridge: Cambridge University Press. 
Bull, P. (2002). Communication under the Microscope: The Theory and Practice of Microanalysis, London: Psychology Press.

—, (2003). The Microanalysis of Political Communication: Claptrap and Ambiguity, London: Routledge.

—, (2008). “'Slipperiness, evasion and ambiguity': equivocation and facework in non-committal political discourse. Journal of Language and Social Psychology 27(4), 324-332.

-, (2010). "Equivocation and communicative skill", The Interrelationship of Business and Communication, M.B. Hinner (ed.), Frankfurt am Main, Germany: Peter Lang GmbH., 69-84.

-, (forthcoming) "What makes a successful politician? The social skills of politics", The Psychology of Politicians, Weinberg, A. (ed.), Cambridge: Cambridge University Press.

Bull, P.E., Elliott, J., Palmer, D., \& Walker, L. (1996). "Why politicians are threefaced: the face model of political interviews". British Journal of Social Psychology 35, 267-284.

Bull, P. \& Fetzer, A. (in press). "Face, facework and political discourse”. International Review of Social Psychology.

Bull, P. \& Law, H. (2009, April). "Punch and Judy politics: Face aggravation in Prime Minister's Question Time”, paper presented at the Annual Conference of the British Psychological Society, Brighton, UK.

Bull, P.E., \& Mayer, K. (1993). "How not to answer questions in political interviews". Political Psychology 14, 651-666.

Bull, P.E. \& Wells, P. (2002). "By invitation only? An analysis of invited and uninvited applause". Journal of Language and Social Psychology 21, 230-244.

Clarke, H.D., Sanders, D., Stewart, M.C. \&Whiteley, P.F. (2004). Political Choice in Britain, Oxford: Oxford University Press.

Clayman, S.E. (1989). "The production of punctuality: social interaction, temporal organization and social structure". American Journal of Sociology 95, 659-691.

—, (1992). "Footing in the achievement of neutrality: the case of news interview discourse", Talk at Work, P. Drew and J. Heritage (eds), Cambridge: Cambridge University Press, 163-198.

Clayman, S. \& Heritage, J. (2002). The News Interview, New York: Cambridge University Press.

Culpeper, J. (1996). “Towards an anatomy of impoliteness”. Journal of Pragmatics 25(3), 349-367.

Goffman, E. (1955). "On face-work: an analysis of ritual elements in social interaction". Psychiatry, 18, 213-231. Reprinted in Interaction Ritual: Essays on Face to Face Behaviour, E. Goffman (1967), Garden City, New York: Anchor, 5-45.

-, (1959/1990). The presentation of self in everyday life, first published by Anchor Books, USA, 1959, London: Penguin Books.

—, (1967). "Where the Action Is", Interaction Ritual: Essays on Face to Face Behaviour, E. Goffman, Garden City, New York: Anchor, 149-270.

Greatbatch, D. (1988). “A turn-taking system for British news interviews”. Language in Society 17, 401-430. 
Hargie, O.D.W. (1997). "Interpersonal communication: a theoretical framework", The Handbook of Communication Skills (2nd ed.), O.D.W. Hargie (ed.), London: Routledge, 29-63.

-, (2006a). "Skill in theory: Communication as skilled performance", The Handbook of Communication Skills (3rd edn.), O.Hargie (ed.), London: Routledge, 7-36.

-, (2006b). "Training in communication skills: research, theory and practice", The Handbook of Communication Skills (3rd edn.), O. Hargie (ed.), London: Routledge, 553-565.

—,(ed.) (2006c). The Handbook of Communication Skills (3rd edn.), London: Routledge.

Hargie, O.D.W. \& Marshall, P. (1986). "Interpersonal communication: a theoretical framework", The Handbook of Communication Skills (1st ed.), O.D.W.Hargie (ed.), London: Croom Helm, 22-56.

Harris, S. (2001). "Being politically impolite: extending politeness theory to adversarial political discourse”. Discourse \& Society 12, 451-472.

Heritage, J.C., Clayman, S.E. \& Zimmerman, D. (1988). "Discourse and message analysis: the micro-structure of mass media messages", Advancing Communication Science: Merging Mass and Interpersonal Processes, R.Hawkins, S.Pingree \& J.Weimann (eds.), Newbury Park: Sage, 77-109.

Heritage, J. \& Greatbatch D. (1986). "Generating applause: a study of rhetoric and response at party political conferences". American Journal of Sociology 92, 110-157.

—, (1991). "On the institutional character of institutional talk: the case of news interviews", Talk and Social Structure, D.Boden \& D.Zimmerman (eds), Cambridge: Polity Press, 93-137.

ILIE, C. (2001). "Unparliamentary language: Insults as cognitive forms of confrontation”, Language and ideology, Vol. II: Descriptive cognitive approaches, R. Dirven, R. Frank \& C. Ilie (eds.), Amsterdam: John Benjamins Publishing Company, 235-263.

-, (2004). "Insulting as (un)parliamentary practice in the British and Swedish Parliaments: A rhetorical approach", Cross-Cultural Perspectives on Parliamentary Discourse, P. Bayley (ed.), Amsterdam: John Benjamins Publishing Company, 45-86.

Johansson, M. (2008). "Presentation of the political self: commitment in electoral media dialogue". Journal of Language and Social Psychology 27, 397-408.

Jucker, J. (1986). News Interviews: a Pragmalinguistic Analysis, Amsterdam: Gieben.

Kienpointer, M. (1997). "Varieties of rudeness: Types and functions of impolite utterances”. Functions of language 4, 251-287.

Sschegloff E.A. (1989). "From interview to confrontation: observations on the Bush/ Rather encounter". Research on Language and Social Interaction 22, 215-240.

Stewart, M.C., \& Clarke, H.D. (1992). "The (un)importance of party leaders: leader images and party choice in the 1987 British election". Journal of Politics 54, 447-470.

The Guardian (2010, May 1). "How many watched each debate?", 13.

Thibault, P. (2003). "Contextualization and social meaning-making practices", Language and Interaction. Discussions with John J. Gumperz, S. Eerdmans, C.L.Prevignano \& P.J.Thibault (eds.), Amsterdam: John Benjamins Publishing Company, 41-62. 
